\title{
The Effect of Unsaponifiable Fraction from Palm Fatty Acid Distillate on Lipid Profile of Hypercholesterolaemia Rats
}

\author{
Teti Estiasih ${ }^{1, *}$, Kgs. Ahmadi ${ }^{2}$, Tri Dewanti Widyaningsih ${ }^{1}$, Emalia Rhitmayanti $^{1}$, Ambar Fidyasari ${ }^{1}$, \\ Katarina Purnomo', Yuyun Wahyuni ${ }^{1}$ \\ ${ }^{1}$ Department of Food Science and Technology, Agricultural Technology Faculty, Brawijaya University, Jl. Veteran, Malang, Jawa \\ Timur, Indonesia \\ ${ }^{2}$ Department of Agroindustry Technology, Faculty of Agriculture, Tribhuwana Tunggadewi University Jl. Telaga Warna, Tlogomas, \\ Malang, Jawa Timur, Indonesia \\ *Corresponding author: teties@yahoo.co.id
}

Received September 19, 2014; Revised December 01, 2014; Accepted December 14, 2014

\begin{abstract}
Physical refining of palm oil by deodorization produces palm fatty acid distillate (PFAD) that contains some bioactive compounds such as vitamin E (tocopherol and tocotrienols), phytosterol, and squalene. These bioactive compounds were accumulated in unsaponifiable fraction. This study aimed to use USF as a source of bioactive compounds for lowering cholesterol that tested in vivo by using hypercholesterolaemia rats. The rats were divided into 4 groups that administered by USF of $0,200,500,1000 \mathrm{mg} / \mathrm{kg}$ bw/day. As comparison, one group of rats was fed by commercial squalene supplement of $90 \mathrm{mg} / \mathrm{kg}$ bw/day. One group of normal rats was used as a control. The results showed that USF of PFAD contained vitamin E $1.96 \%$, phytosterols $0.55 \%$, and squalene $32.30 \%$. Vitamin E of USF comprised of $83 \%$ tocotrienols and the remaining is tocopherol. Phytosterols of USF contained $0.42 \%$ beta sitosterol and $0.13 \%$ campesterol. The result showed that USF doses significantly affected blood serum total cholesterol reduction. Higher dose of USF caused greater reduction of serum blood cholesterol level. The highest decline of blood serum total cholesterol was found at USF dose of $1000 \mathrm{mg} / \mathrm{kg} \mathrm{bw} / \mathrm{day}$. At dose of $1000 \mathrm{mg} / \mathrm{kg}$ bw/day, blood serum cholesterol level reached normal after USF administration for 4 weeks. The blood serum triglyceride level decreased in line with increasing USF doses. The sharp decline of blood serum triglyceride level was found at USF dose of $1000 \mathrm{mg} / \mathrm{kg}$ bw/day and at the end of experiment (week 4), the blood serum triglyceride level reached normal. Higher dose of USF resulted on greater decrease of LDL cholesterol level. The highest decline of LDL cholesterol level was found on USF $1000 \mathrm{mg} / \mathrm{kg}$ bw/day. Increasing USF dose resulted in increasing blood serum HDL cholesterol level. The higher rise of blood serum HDL cholesterol level was found at USF dose of $1000 \mathrm{mg} / \mathrm{kg}$ bw/day. Commercial squalene at dose of $90 \mathrm{mg} / \mathrm{kg}$ bw/day was less effective in reducing total cholesterol, LDL cholesterol, and troglyceride, as well as in rising HDL cholesterol level than USF $200 \mathrm{mg} / \mathrm{kg}$ bw/day (equivalent to squalene $64.60 \mathrm{mg} / \mathrm{kg}$ bw/day). This finding proved that multi components of bioactive compounds in USF improved blood lipid profile synergistically.
\end{abstract}

Keywords: hypercholesterolaemia, lipid profile, palm fatty acid distillate, phytosterol, squalene, tocopherol, tocotrienol, unsaponifiable fraction

Cite This Article: Teti Estiasih, Kgs. Ahmadi, Tri Dewanti Widyaningsih, Emalia Rhitmayanti, Ambar Fidyasari, Katarina Purnomo, and Yuyun Wahyuni, "The Effect of Unsaponifiable Fraction from Palm Fatty Acid Distillate on Lipid Profile of Hypercholesterolaemia Rats." Journal of Food and Nutrition Research, vol. 2, no. 12 (2014): 1029-1036. doi: 10.12691/jfnr-2-12-26.

\section{Introduction}

Palm frying oil is produced through several refining steps, consisted of degumming, bleaching, and physical refining to remove odoreous compounds and free fatty acids. Physical refining process by deodorization produces palm fatty acid distillate (PFAD) as a by-product. Gapoor et al (2002) reported that PFAD contained mainly free fatty acids, and other minor contstituent comprised of tocopherols, tocotrienols, phytosterols, and squalene [1].
For every 100 ton of CPO, PFAD is produced about 3.66 ton [2], because its production is $4 \%$ based on CPO [3]. Unfortunately, PFAD is used as fatty acid source for non food industries [4] such as such as soap, feed, and oleo chemical industries [5] by neglecting the existence of bioactive compounds. PFAD could be used integratively as a source of bioactive compounds and free fatty acids for oleo chemical industries [6].

As much as $5-57 \%$ of tocotrienols and tocopherols lost from CPO during deodorization and mostly are accumulated in PFAD with concentration of 0.7-1.0\% [7]. 
Squalene was found in PFAD that reaches 1.03\% [8]. Other minor bioactive compound that found in PFAD is phytosterols with concentration of $0.37 \%$ [1]. All of these bioactive compounds are not saponified during saponification, therefore they are accumulated in unsaponifiable fraction (USF) of PFAD [9]. Our previous study showed that USF could be separated from saponifiable fraction by simple saponification. The bioactive compounds of USF are vitamin $\mathrm{E}$ of $0.80 \%$, phytosterols of $9.16 \%$, squalene of $1.14 \%$ [6]. The difference of PFAD as vitamin E containing material form other vitamin E sources is rich in tocotrienols [10,11]. Lewis (2001) indicated that tocotrienols have hypocholesterolaemic property and have the ability to reduce LDL cholesterol level [12].

Phytosterol lowers blood cholesterol level by inhibiting cholesterol absorption [13], so it has hypocholesterolaemic effect $[14,15,16]$. The mechanism of cholesterol lowering properties of phytosterol is still unclear, but Bonsdorff-Nikander (2005) proposed that phytosterols compete with cholesterol in micelle formation, phytosterols cocrystallize with cholesterols, and phytosterols inhibit ACAT activity in cholesterol synthesis [17].

Squalene as one of bioactive compounds in PFAD, also has cholesterol lowering property [18] by increasing fecal excretion of bile acid [19,20,21]. In contrary, other study showed that squalene increase cholesterol level [22], due to the increasing extent of cholesterol synthesis [23].

It is possible that bioactive compounds of USF synergistically have beneficial effects on lipid profile in hypercholesterolaemia condition. At this study, the abillity of USF from PFAD as cholesterol lowering compounds was investigated including the effective dose to improve lipid profile.

\section{Materials and Methods}

\subsection{Materials}

PFAD was kindly obtained from a palm oil refinery, PT Salim Ivomas Pratama at Surabaya, Indonesia. Chemical reagents used were vitamin $\mathrm{E}$ standard ( $\alpha$ tocopherol, $\alpha$ tocotrienol, $\beta$ tocotrienol, $\delta$ tocotrienol), squalene, phytosterols (campesterol, stigmasterol and $\beta$ sitosterol), MSTFA (methyl N-trimethylsilyl-trifluoracetamide) (Santa Cruz Biotech USA), HPLC grade solvents (Merck) and other chemical reagents for analysis (Merck), Wistar male rats with body weight of 150-200 g and age of 8-12 weeks, AIN-93M standard diet with slight modification, atherogenic diets, commercial squlene supplement, and serum blood lipid profile analysis kit (Diasys).

\subsection{USF Preparation from PFAD}

The preparation of USF was conducted by saponification method [6]. Samples of PFAD and USF were analyzed for vitamin E, phytosterols, and squalene.

\subsubsection{Phytosterols Analysis}

Phytosterols analysis was followed method of Khatoon et al (2010). About $1 \mathrm{mg}$ of unsaponifiable fraction of PFAD was added by ethanol $1 \mathrm{~mL}$ and subsequently filtered. $20 \mu \mathrm{L}$ of sample solution was injected into high performance liquid chromatography (Shimadzu LC20AT) with C18 PPODS column $250 \times 4.6 \mathrm{~mm}$ and uv vis detector (Shimadzu SPD20A) at wavelength of $206 \mathrm{~nm}$. Mobile phase was methanol: water (99:1 v: v) with flow rate of 1 $\mathrm{mL} / \mathrm{min}$. Identification and quantification was conducted by using phytosterols (stigmasterol, $\beta$ sitosterol, campesterol) standard (Santa Crus Biotech, USA) that injected into HPLC separately [9].

\subsubsection{Vitamin $\mathrm{E}$ analysis}

This procedure was according to Ball (1988). About 1 mg of unsaponifiable fraction of PFAD was added by ethanol $1 \mathrm{~mL}$ and then filtered. $20 \mu \mathrm{L}$ of sample solution was injected into high performance liquid chromatography (Shimadzu LC20AT) with C18 PPODS column 250×4.6 $\mathrm{mm}$ and uv vis detector (Shimadzu SPD20A) at wavelength of $295 \mathrm{~nm}$. Mobile phase was methanol: water (95:5 v: v) with flow rate of $1 \mathrm{~mL} / \mathrm{min}$. Identification and quantification was conducted by using $\alpha$ tocopherol, $\alpha$ tocotrienol, $\beta$ tocotrienol, $\delta$ tocotrienol and $\gamma$ tocotrienol standards (Santa Cruz Biotech, USA) that injected into HPLC separately [24].

\subsubsection{Squalene Analysis}

This analysis was using GC MS with derivatization method according to Mendez et al (2003) by using MSTFA. About $10 \mathrm{mg}$ of unsaponifiable fraction of PFAD was put into reaction tube and added by MSTFA $10 \mu \mathrm{L}$. The mixture was heated at $60^{\circ} \mathrm{C}$ for $15 \mathrm{~min}$. External standard of 1-docosanol was used for quantification that prepared by diluting $1 \mathrm{mg}$ of this standard with MSTFA $100 \mu \mathrm{L}$ and the mixture was heated at $60^{\circ} \mathrm{C}$ for $15 \mathrm{~min} .1 \mu \mathrm{L}$ of derivatized sample was injected into GC MS (GCMS-QP2010S Shimadzu) (with column (AGILENT DB-1) $30 \mathrm{~m}$, i.d. $0.25 \mathrm{~mm}$, helium as carrier gas and ionization EI 70 Ev. GC operational condition was column oven temperature of $80^{\circ} \mathrm{C}$, injector temperature of $310^{\circ} \mathrm{C}$, pressure of $16.5 \mathrm{kPa}$, total flow rate of $80.0 \mathrm{~mL} / \mathrm{min}$, column flow rate of $0.50 \mathrm{~mL} / \mathrm{min}$, linear velocity of $26.1 \mathrm{~cm} / \mathrm{s}$, supporting gas rate of $3.0 \mathrm{ml} / \mathrm{min}$ and split ratio of 153.0 . Initial temperature was $80^{\circ} \mathrm{C}$ and holded for $5 \mathrm{~min}$. Temperature was increased with rate of $10^{\circ} \mathrm{C} / \mathrm{min}$ to the temperature of $305^{\circ} \mathrm{C}$ and holded for 25 min. MS analysis was conducted at ion source temperature of $250^{\circ} \mathrm{C}$, interface temperature of $310^{\circ} \mathrm{C}$, solvent cut time of $4.80 \mathrm{~min}$, scan speed of 1250 , start $\mathrm{m} / \mathrm{z} 28.0$ and end $\mathrm{m} / \mathrm{z}$ 600.0. Squalene standard (Santa Cruz Biotech, USA) was used as external standard [25].

\subsection{Bioassay of Cholesterol Lowering Effect of USF}

The protocol of bioassay had been approved for ethical clearence No. 190-KEP-UB from Animal Care and Use Committee, Brawijaya University. As many as 24 Wistar male rats were used in this study. Each rat was caged individually and adapted to laboratory enviroment for 7 days. During adaptation, rats were fed by standard diet of AIN-93 M with slight modification (Table 1) [26]. Rats were divided into 6 groups and each group comprised of 4 rats. One group was normal rats without USF treatment. Other four groups were hypercholesterolaemia rats treated by USF $0,200,500,100 \mathrm{mg} / \mathrm{kg}$ bw/day and one group was hypercholesterolaemia rats treated by commercial 
squalene at dose of $90 \mathrm{mg} / \mathrm{kg}$ bw/day. All groups of hypercholesterolaemia rats were fed by atherogenic diet (Table 1).

Table 1. Composition of modified AIN-93M and atherogenic diet

\begin{tabular}{ccc}
\hline \multirow{2}{*}{ Component } & \multicolumn{2}{c}{ Composition (g/kg diet) } \\
\cline { 2 - 3 } & Modified AIN-93M [1] & Atherogenic Diet \\
\hline Maize starch & 620,692 & 620,692 \\
Casein & 140 & 116,528 \\
Sucrose & 100 & 100 \\
Soybean oil & 40 & 40 \\
CMC & 50 & 50 \\
AIN mineral mix & 35 & 35 \\
AIN vitamin mix & 10 & 10 \\
L-cystin & 1,8 & 1,8 \\
Choline bitartrate & 2,5 & 2,5 \\
TBHQ & - & - \\
Cholic acid & - & 2 \\
Cholesterol crystal & - & 20 \\
Tallow & - & 185 \\
\hline
\end{tabular}

Rats were treated by USF and squalene administration for 4 weeks, and body weight of each rat was measured daily as well as the quantity of feed consumption. Treatment by USF administration was conducted after total cholesterol level of rats reached $>130 \mathrm{mg} / \mathrm{dL}$. Lipid profile was analyzed at week $0,1,2,3$, and 4 to measure LDL cholesterol, triglyceride, and total cholesterol of serum blood. Blood was taken by retro orbital plexus method and centrifuged at $4000 \mathrm{rpm}$ for $10 \mathrm{~min}$ to separate blood serum. Blood serum total cholesterol, triglyceride, and HDL cholesterol levels were measured by method of CHOD-PAP, GPO-PAP, and triglyceride kit, respectively. Meanwhile, blood serum LDL level was calculated based on the data of total cholesterol, triglyceride, and HDL cholesterol.

\section{Results}

\subsection{Bioactive Compounds of PFAD and USF}

Bioactive compounds found in PFAD are vitamin E, phytosterols, and squalene. Generally, phytosterols were the most prominent bioactive compound found in PFAD (Table 2). USF and PFAD had different concentration and composition of bioactive compounds. USF had higher vitamin E and squalene concentration than PFAD (Table 2), meanwhile phytosterols of USF was lower that that in PFAD.

Table 2. The concentration of bioactive compounds of PFAD and USF

\begin{tabular}{ccccc}
\hline \multirow{2}{*}{ Bioactive Compound } & \multicolumn{2}{c}{ PFAD } & \multicolumn{2}{c}{ USF } \\
\cline { 2 - 5 } & ppm & $\%$ & ppm & $\%$ \\
\hline Vitamin E & 195,60 & 0,1956 & 19.600 & 1,96 \\
Phytosterols & $7.476,56$ & 0,7476 & 5.500 & 0,55 \\
Squalene & $2.373,27$ & 0,2373 & 323.000 & 32,30 \\
\hline
\end{tabular}

The increase of vitamin $\mathrm{E}$ and squalene was related to elimination of free fatty acid as the major component of PFAD during saponification. But, the decrease of phytosterols was still unknown. Our previous study showed that all of the bioactive compounds increased in USF after PFAD saponification, including phytosterols with the concentration in USF was 9.18 and 7.77\% [6].

The concentration of bioactive compounds in USF was high. The phytosterols content of USF was $0.55 \%$ or 5.5 $\mathrm{mg} / \mathrm{g}$, vitamin E $1.96 \%$ or $19.6 \mathrm{mg} / \mathrm{g}$, and squalene $32.30 \%$ or $323 \mathrm{mg} / \mathrm{g}$. Vitamin E of USF comprised of $83 \%$ tocotrienols and the remaining is tocopherol.
Phytosterols was the lowest concentration of bioactive compounds of PFAD. The concentration of phytosterols in USF was $0.55 \%$ that meant $1 \mathrm{~g}$ of USF contained $5.5 \mathrm{mg}$ of phytosterols. Phytosterols of USF contained $0.42 \%$ beta sitosterol and $0.13 \%$ campesterol. Meanwhile, squalene was the highest bioactive compound in USF with concentration of $32.30 \%$ or in $1 \mathrm{~g}$ of USF would provide $323 \mathrm{mg}$ squalene.

\subsection{The Effect of USF on Blood Serum Total Cholesterol Level}

USF administration to hypercholesterolaemia rats decreased blood serum total cholesterol level. The degree of total cholesterol level decline depended on USF doses (Figure 1). Group of hypercholesterolaemia rats without USF administration showed high blood serum total cholesterol level and total cholesterol level slightly decreased during 4 weeks experiment. USF administration at dose of $1000 \mathrm{mg} / \mathrm{kg}$ bw/day revealed blood serum total cholesterol level that reached normal (blood serum total cholesterol level $\pm 100 \mathrm{mg} / \mathrm{dL}$ ) after 4 weeks administration.

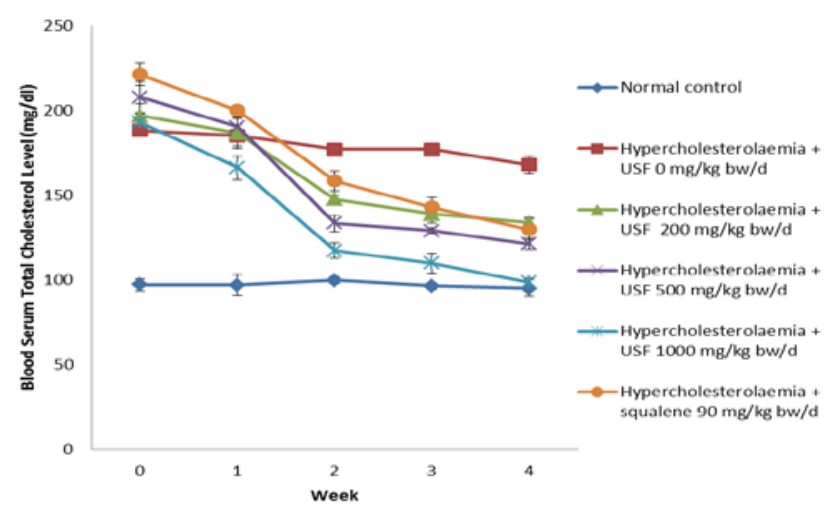

Figure 1. Blood serum total cholesterol level after USF administration at various doses

USF doses significantly affected blood serum total cholesterol reduction. Higher dose of USF caused greater reduction of serum blood cholesterol level. Thus, the highest decline of blood serum total cholesterol was found at USF dose of $1000 \mathrm{mg} / \mathrm{kg}$ bw/day. At the lowest dose (200 mg/kg bw/day), the phytosterol was $1.1 \mathrm{mg} / \mathrm{kg}$ bw/day and squalene was $64.60 \mathrm{mg} / \mathrm{kg}$ bw/day. The USF at dose of $200 \mathrm{mg} / \mathrm{kg}$ bw/day was more efective in reducing blood serum total cholesterol than pure squalene at dose of $90 \mathrm{mg} / \mathrm{kg} \mathrm{bw/day,} \mathrm{although} \mathrm{the} \mathrm{dose} \mathrm{of} \mathrm{squalene}$ at USF was lower.

Administration of USF at dose of 200 and $500 \mathrm{mg} / \mathrm{kg}$ bw/day showed similar pattern, but the decline of blood serum cholesterol level was sharp at dose of $1000 \mathrm{mg} / \mathrm{kg}$ bw/day. At dose of $1000 \mathrm{mg} / \mathrm{kg}$ bw/day, blood serum cholesterol level reached normal after USF administration for 4 weeks.

\subsection{The Effect of USF on Blood Serum Triglyceride Level}

Serum triglyceride level is one of indicator of blood lipid profile. The changes of blood serum triglyceride level of each group of rats were shown at Figure 2. The blood serum triglyceride level decreased in line with 
increasing USF doses. The sharp decline of blood serum triglyceride level was found at USF dose of $1000 \mathrm{mg} / \mathrm{kg}$ bw/day and at the end of experiment (week 4), the blood serum triglyceride level reached normal.

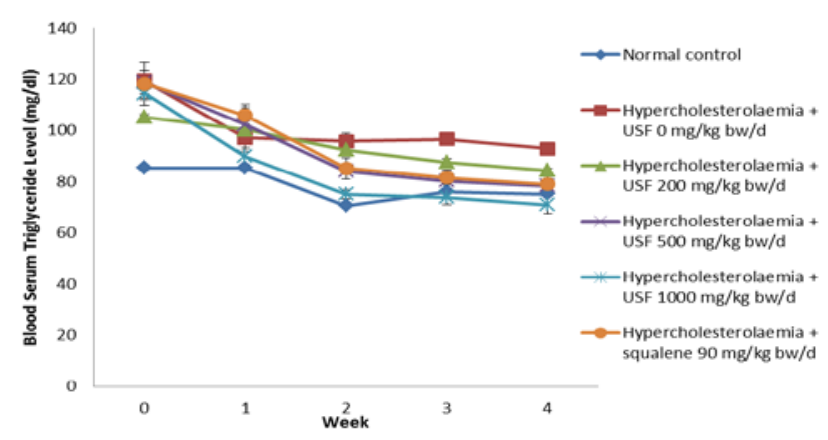

Figure 2. Blood serum triglyceride level after USF administration at various doses

As blood serum total cholesterol level, the decrease of blood serum triglyceride level of USF at dose $200 \mathrm{mg} / \mathrm{kg}$ bw/day almost similar to squalene supplement administration at dose of $90 \mathrm{mg} / \mathrm{kg}$ bw/day, although at USF dose of $200 \mathrm{mg} / \mathrm{kg}$ bw/day the squalene dose was $64.60 \mathrm{mg} / \mathrm{kg}$ bw/day. It meant that USF was more effective in lowering blood serum triglyceride level. USF administration at dose of $1000 \mathrm{mg} / \mathrm{kg}$ bw/day for 4 weeks resulted in normal triglyceride level.

\subsection{The Effect of USF on Blood Serum LDL Cholesterol Level}

The effect of USF doses on blood serum LDL cholesterol level was shown in Figure 3. Blood serum LDL cholesterol level decreased in all USF doses, meanwhile control groups still showed no reduction in LDL cholesterol level. The decrease in blood serum LDL cholesterol level had occurred since week 1 of the treatments. Group of rat adminstered by USF $1000 \mathrm{mg} / \mathrm{kg}$ bw/day had approximate normal LDL cholesterol level at week 4.

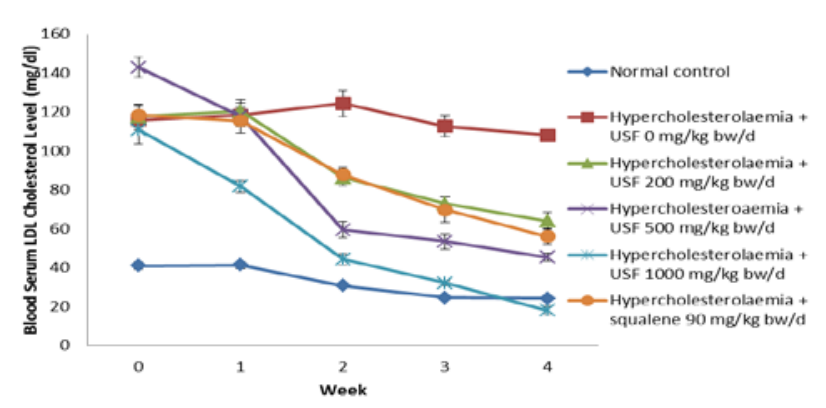

Figure 3. Blood serum LDL cholesterol level after USF administration at various doses

Blood serum LDL cholesterol level reduction due to USF treatment showed that USF was effective to lower LDL cholesterol level. This reduction was caused by the presence of phytosterols, squalene, and vitamin E in USF. Higher dose of USF resulted on greater decrease of LDL cholesterol level. The highest decline of LDL cholesterol level was found on USF $1000 \mathrm{mg} / \mathrm{kg}$ bw/day. In reducing LDL cholesterol level, squalene supplement at dose of 90 $\mathrm{mg} / \mathrm{kg}$ bw/day showed almost as effective as USF dose of $200 \mathrm{mg} / \mathrm{kg}$ bw/day that contained $64.60 \mathrm{mg}$ squalene.

\subsection{The Effect of USF on Blood Serum HDL Cholesterol Level}

USF intake for 4 weeks increased blood serum HDL level (Figure 4). HDL cholesterol increase related to USF adminstration that reduce total cholesterol and LDL cholesterol levels simultaneously. Increasing USF dose resulted in increasing blood serum HDL cholesterol level.

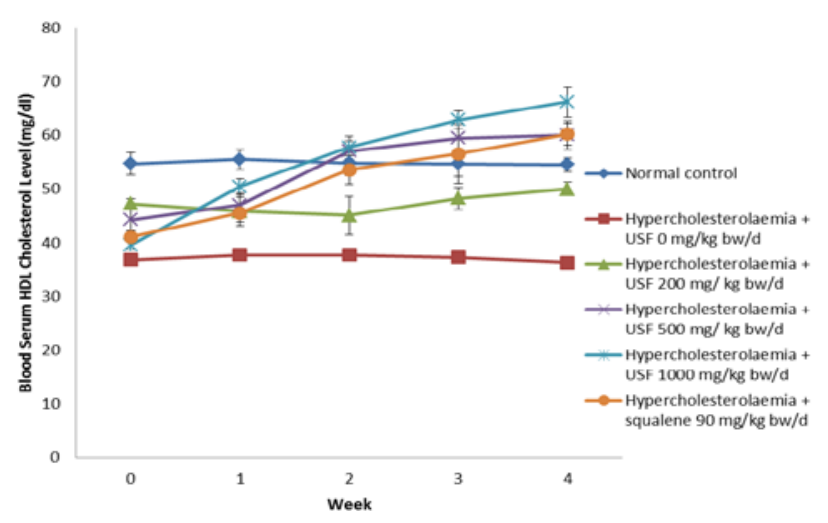

Figure 4. Blood serum HDL cholesterol level after USF administration at various doses

The higher rise of blood serum HDL cholesterol level was found at USF dose of $1000 \mathrm{mg} / \mathrm{kg}$ bw/day. Commercial squalene at dose of $90 \mathrm{mg} / \mathrm{kg}$ bw/day was less effective in rising HDL cholesterol level than USF $200 \mathrm{mg} / \mathrm{kg}$ bw/day (equivalent to squalene $64.60 \mathrm{mg} / \mathrm{kg}$ bw/day). This finding proved that multi components of bioactive compounds in USF improved blood lipid profile synergistically.

\section{Discussions}

\subsection{Bioactive Compounds of PFAD}

Bioactive compounds found in PFAD are vitamin E, phytosterols, and squalene. Palm oil contained vitamin E 600-1.000 ppm, phytosterols 300-620 ppm, carotenoid 500-700 ppm, squalene 250-540 ppm, phospholipids 20100 ppm, co-enzyme Q10 10-80 ppm, and poliphenol 4070 ppm [18]. Meanwhile, our previous study [27] showed that PFAD from several palm oil refineries contained vitamin E 65-281 ppm, phytosetrols 407-6012 ppm, and squalene 206-1274 ppm. Vitamin E of PFAD comprised of $\alpha$-tocopherol 9-135 ppm, $\alpha$-tocotrienol 12-52 ppm, $\delta$ tocotrienol 5-64 ppm, $\gamma$-tocotrienol 32-118 ppm. Meanwhile phytosterols of PFAD consisted of $\beta$-sitosterol 382-3,576 ppm, stigmasterol 11-1548 ppm, and campesterol 19-1,720 ppm.

USF and PFAD had different concentration and composition of bioactove compounds. Generally, USF had higher bioactive compounds than PFAD (Table 2) because they were accumulated in unsaponifiable fraction [9]. Vitamin E increased 245\% in USF compared to PFAD, phytosterols decreased $73 \%$, and squalene increased $13611 \%$. The increase of vitamin $\mathrm{E}$ and squalene was related to elimination of free fatty acid as the major component of PFAD during saponification. But, the decrease of phytosterols was still unknown. Our previous study [6] showed that all of the bioactive compounds increased in USF after PFAD saponification, including 
phytosterols with the concentration in USF was 9.18 and $7.77 \%$. The phytosterols content of USF was $0.55 \%$ or 5.5 $\mathrm{mg} / \mathrm{g}$, vitamin E $1.96 \%$ or $19.6 \mathrm{mg} / \mathrm{g}$, and squalene $32.30 \%$ or $323 \mathrm{mg} / \mathrm{g}$.

The concentration of bioactive compounds in USF was high. Consumption of $1 \mathrm{~g}$ USF per day will provide 19.6 $\mathrm{mg}$ that meets the daily requirement of vitamin $\mathrm{E}$ or $140 \%$ of daily reference value. Other sources of vitamin $\mathrm{E}$ are rice bran (90.9 mg/100 g), wheat sprout (153.7 mg/100 g), coconut (1.1 mg/100 g), soybean (7.8 mg/100 g), and olive (11.9 mg/100 g) [28]. Meanwhile, USF contained vitamin $\mathrm{E}$ of $1960 \mathrm{mg} / 100 \mathrm{~g}$.

Phytosterols was the lowest concentration of bioactive compounds of PFAD. The concentration of phytosterols in USF was $0.55 \%$ that meant $1 \mathrm{~g}$ of USF contained $5.5 \mathrm{mg}$ of phytosterols. This concentration was low compared to other sources such as crude corn fiber oil (8.79\%), crude corn kernel oil (7.94\%), refined corn kernel oil (1.11\%), and commercial corn oil (0.74\%) [29]. In palm oil, phytosterol is a minor component that comprises of campesterol, stigmasterol, and $\beta$-sitosterol [11]. Squalene was the highest bioactive compound in USF with concentration of $32.30 \%$ or in $1 \mathrm{~g}$ of USF would provide $323 \mathrm{mg}$ squalene.

\subsection{The Effect of USF on Lipid Profile Improvement}

USF administration to hypercholesterolaemia rats decreased blood serum total cholesterol level. The degree of total cholesterol level decline depended on USF doses (Figure 1). Group of hypercholesterolaemia rats without USF administration showed high blood serum total cholesterol level and total cholesterol level slightly decreased during 4 weeks experiment. USF administration at dose of $1000 \mathrm{mg} / \mathrm{kg}$ bw/day revealed blood serum total cholesterol level that reached normal (blood serum total cholesterol level $\pm 100 \mathrm{mg} / \mathrm{dL}$ ) after 4 weeks administration.

The mechanism of USF in reducing blood serum total cholesterol level was related to the action of phytosterols. Phytosterols inhibits cholesterol absorption in the digestive system. The higher the dose of USF made higher cholesterol absorption inhibition. According to Mel'nikov et al (2003), phytosterols are the compounds that have very similar structure to cholesterol [30]. Phytosterols/stanols, which are structurally related to cholesterol, are thought to compete with cholesterol for solubilisation into mixed micelles. This leads to a reduced absorption of cholesterol and/or to an enhanced efflux of cholesterol back into the intestinal lumen due to a higher expression of the ABC transporter. Both mechanisms ultimately result in an increased faecal output of cholesterol [31]

Equal contents of cholesterol and either campesterol, stigmasterol, sitosterol, or stigmastanol (sitostanol) decreased cholesterol solubility in micelles by approximately 50\% compared to no phytosterol present, with stigmasterol performing slightly better than sitosterol. Phytosterols competed with cholesterol in a dosedependent manner. Unsaturated fatty acids increased the micelle solubility of sterols as compared with saturated or no fatty acids. No differences were detected in the size of the model micelles. Together, these data indicate that stigmasterol combined with saturated fatty acids may be more effective at lowering cholesterol micelle solubility in vivo. Four different phytosterols decreased cholesterol solubility to a very similar extent. Stigmasterol was, by a small margin, the most potent of the four, decreasing the concentration of micellar cholesterol and total solubilized sterols [32]. In this study, stigmasterol was not found in USF of PFAD. It was supposed that $\beta$ sitosterol and campesterol in USF had a role in decreasing cholesterol level.

Addition of phytosterol ester decreased the incorporation of cholesterol into the duodenum aqueous phase including micelles. Phytosterol ester either dispersed in fat during a meal or micro-dispersed in a liquid form after a meal resulted in a markedly reduced occurrence of meal-derived cholesterol in the circulation at a comparable extent [33]. Previouesly, the study of Chen et al (2010) showed that phytosterols intake of 2 $\mathrm{g} / \mathrm{kg}$ feed for 5 weeks reduced $40 \%$ cholesterol level in the liver, 31\% in aorta, and 19\% in renal [34].

According to Kamal-Eldin and Moazzami (2009), the role of phytosterols is not only by inhibiting cholesterol absorption but also inhibiting cholesterol synthesis through HMG-CoA reductase inhibition [35]. In phytosterolemia, a condition that indicated by elevated sitosterol level, the activity of HMG CoA reductase is low [36].

Bartnikoswka (2009) concluded that the extent of the hypocholesterolemic effect of phytosterols depends on various factors of which the most important are: (i) phytosterols origin determining their profile, (ii) the dose and manner of dosage (as one dose or divided into portions), (iii) duration of treatment, and (iv) age of the patient as well as the type and intensity of lipid metabolism disorders [37].

USF contained squalene of $32.30 \%$. Some studies showed that squalene from animal and vegetable have different effect on cholesterol metabolisms. Animal squalene such as shark squalene has hypercolesterolaemic property, meanwhile vegetable squalene such as amaranth squalene shows otherwise [19,20,21,22]. This study showed that palm squalene in USF had hypocholesterolaemic effects, as well as squalene supplement also lowered total cholesterol, although the effect was not less effective compared to squalene in USF. The level of squalene intake from USF at various doses was $0 \mathrm{mg}$ (USF $0 \mathrm{mg} / \mathrm{kg}$ bw/day), $64.60 \mathrm{mg}$ (USF 200 $\mathrm{mg} / \mathrm{kg} \mathrm{bw),} 161.5 \mathrm{mg}$ (USF $500 \mathrm{mg} / \mathrm{kg}$ bw/day), and 323 mg (USF $1000 \mathrm{mg} / \mathrm{kg}$ bw/day). Study of Miettinen et al. (1994) showed that administration of squalene $0.5 \mathrm{~g} /$ day decreased the serum lipid concentration.

In the 9 -wk study $85 \%$ of squalene was absorbed but cholesterol synthesis measured by fecal analysis was insignificantly increased. Subsequent conversion of squalene to cholesterol had markedly inhibited presqualene cholesterol synthesis and HMG-CoA reductase activity and that these inhibitions may be enhanced by long-term squalene administration. The effect of squalene on blood LDL cholesterol is dose dependent. Small squalene doses obviously inhibit endogenous presqualene cholesterol synthesis with no effects on LDL receptors or serum cholesterol. Large amounts of squalene-rich olive oil with long-term use might have harmful effects on the serum cholesterol concentration [38]. 
Beside squalene and phytosterols, USF also contained tocotrienols $1.96 \%$. It was reported that tocotrienols, mainly gamma and delta tocotrienols, down regulate cholesterol synthesis by affecting gene that responsible to HMG reductase synthesis [39]. Administration of USF at doses of 200, 500, and $1000 \mathrm{mg} / \mathrm{kg}$ bw/day provided tocotrienols $2.92 \mathrm{mg}, 9.8$, and $19,6 \mathrm{mg} / \mathrm{kg} \mathrm{bw} /$ day, respectively.

USF doses significantly affected blood serum total cholesterol reduction. Higher dose of USF caused greater reduction of serum blood cholesterol level. Thus, the highest decline of blood serum total cholesterol was found at USF dose of $1000 \mathrm{mg} / \mathrm{kg}$ bw/day. At the lowest dose (200 mg/kg bw/day), the phytosterol was $1.1 \mathrm{mg} / \mathrm{kg}$ bw/day and squalene $64.60 \mathrm{mg} / \mathrm{kg}$ bw/day. The USF at dose of $200 \mathrm{mg} / \mathrm{kg}$ bw/day was more efective in reducing blood serum total cholesterol than pure squalene at dose of $90 \mathrm{mg} / \mathrm{kg} \mathrm{bw} /$ day, although the dose of squalene at USF was lower. This was due to the synergistic effect of other bioactive compounds in USF such as phytosterols and vitamin E.

Administration of USF at doses of 200 and $500 \mathrm{mg} / \mathrm{kg}$ bw/day showed similar pattern, but the decline of blood serum cholesterol level was sharp at dose of $1000 \mathrm{mg} / \mathrm{kg}$ bw/day. At dose of $1000 \mathrm{mg} / \mathrm{kg}$ bw/day, blood serum cholesterol level reached normal after USF administration for 4 weeks.

\subsection{The Effect of USF on Blood Serum Triglyceride Level}

Serum triglyceride level is one of indicator of blood lipid profile. The changes of blood serum triglyceride level of each group of rat were shown at Figure 2. The blood serum triglyceride level decreased in line with increasing USF doses. The sharp decline of blood serum triglyceride level was found at USF dose of $1000 \mathrm{mg} / \mathrm{kg}$ bw/day and at the end of experiment (week 4), the blood serum triglyceride level reached normal.

As blood serum total cholesterol level, the decrease of blood serum triglyceride level of USF at dose $200 \mathrm{mg} / \mathrm{kg}$ bw/day almost similar to squalene supplement administration at dose of $90 \mathrm{mg} / \mathrm{kg}$ bw/day, athough at USF dose of $200 \mathrm{mg} / \mathrm{kg}$ bw/day the squalene dose was $64.60 \mathrm{mg} / \mathrm{kg}$ bw/day. It meant that USF was more effective in lowering blood serum triglyceride level.

The phytosterols in USF was also supposed to decrease blood serum triglyceride level. Bile acid secretion increased by phytosterols administration from USF and affected blood serum triglyceride level. Bile acid influenced fat absorption, and fat absorption was interfered by high bile acid secretion that caused in the decrease of blood serum triglyceride level. USF administration at dose of $1000 \mathrm{mg} / \mathrm{kg}$ bw/day for 4 weeks resulted in normal triglyceride level. Low level of triglyceride leads to reduction of cholesterol level. Triglyceride in our body is catabolized into acetyl Co A, a precursor in cholesterol synthesis [23]. Thus, low triglyceride level affects the cholesterol synthesis that imply to low blood cholesterol level.

\subsection{The Effect of USF on Blood Serum LDL Cholesterol Level}

Elevated concentrations of plasma LDL-cholesterol are recognised as a major risk factor for the development of premature CVD [40]. Among lipoproteins, the property of LDL cholesterol is contrary to the HDL, that high LDL cholesterol leads to atherosclerosis meanwhile HDL cholesterol has the preventive effect. In LDL, lipid is incorporated into lipoprotein in higher amount than protein. USF administration increased HDL cholesterol in concomitant with LDL cholesterol level reduction. The effect of USF doses on blood serum LDL cholesterol level was shown in Figure 3.

Blood serum LDL cholesterol level decreased in all USF doses, meanwhile control groups still showed no reduction in LDL cholesterol level. The decrease in blood serum LDL cholesterol level had occurred since week 1 of the treatments. Group of rat adminstered by USF 1000 $\mathrm{mg} / \mathrm{kg}$ bw/day had approximate normal LDL cholesterol level at week 4.

USF was effective to lower LDL cholesterol level due to the presence of phytosterols, squalene, and vitamin E. Piironen et al. (2000) and Cohen (2008) indicated that phytosterols inhibit cholesterol absorption from foodstuffs and phytosterols also inhibit reabsorption of cholesterol from bile acid [15,41]. Phytosterols have similar structure to cholesterol. Therefore they can replace cholesterol from micelle. According to Kamal-Eldin and Moazzami (2009), daily consumption of phytosterols $1-2$ g can reduce LDL cholesterol level 10-20\% [35]. This research showed that administration of phytosterols $1.1 \mathrm{mg}-5.5 \mathrm{mg} / \mathrm{kg}$ bw/day reduced LDL cholesterol level 7-140\%.

Other bioactive compounds in USF that responsible to lower LDL cholesterol were squalene and vitamin E mainly tocotrienols. Some studies showed that there were inconsistent results on LDL cholesterol level after squalene intake $[21,22]$. Long-term study showed that the serum concentration of total cholesterol was increased by the large squalene intake $(1 \mathrm{~g} / \mathrm{d}$ ) because of the augmented number of LDL particles with low surface lipids (free cholesterol and phospholipids), possibly a consequence of increased cholesterol synthesis from squalene [38]. Shin et al (2004) supposed that the sources of squalene influenced the effect of squalene on LDL cholesterol level. Squalene from vegetable origin tended to decrease LDL cholesterol level, meanwhile squalene from animal has otherwise effect [20].

Response of plasma and lipoproteins to tocotrienols may be determined by the dose of tocotrienol supplementation. Tocotrienol isomers $(\alpha, \Upsilon$, and $\delta$ tocotrienols) were present in the circulating plasma and lipoproteins (Triglyceride Rich Particle/TRP, LDL, and HDL) after tocotrienol supplementation [42]. This study showed tocotrienols from USF might have a role in reducing LDL cholesterol level.

Higher dose of USF resulted on greater decrease of LDL cholesterol level. The highest decline of LDL cholesterol level was found on USF $1000 \mathrm{mg} / \mathrm{kg}$ bw/day. In reducing LDL cholesterol level, squalene supplement at dose of $90 \mathrm{mg} / \mathrm{kg}$ bw/day showed almost as effective as USF dose of $200 \mathrm{mg} / \mathrm{kg}$ bw/day that contained $64.60 \mathrm{mg}$ squalene/kg bw/day. This was due to not only one bioactive compound that responsible to LDL cholesterol reduction, but also multi bioactive components that have synergistic role. 


\subsection{The Effect of USF on Blood Serum HDL Cholesterol Level}

HDL has a function to transport cholesterol from peripheral tissue to liver. Low blood HDL cholesterol level related to high risk of coronary heart disease [43]. USF intake for 4 weeks increased blood serum HDL level (Figure 4). HDL cholesterol increase related to USF administration that reduced total cholesterol and LDL cholesterol levels simultaneously. Increasing USF dose resulted in increasing blood serum HDL cholesterol level.

In blood plasma, cholesterol is not soluble so it requires HDL for transporting cholesterol into liver. Liver will eliminate the excess of cholesterol by bile acid synthesis and secretion. The cholesterol transport into liver is one mechanism to maintain cholesterol level and balance in blood plasma. The decline in LDL cholesterol also causes decreasing cholesterol transport into liver and concomitantly increases HDL cholesterol. HDL cholesterol increases cholesterol transport from blood into liver thus reduces blood total cholesterol. In liver, cholesterol is converted into bile acid that was secreted into feses [41].

The highest rise of blood serum HDL cholesterol level was found at USF dose of $1000 \mathrm{mg} / \mathrm{kg}$ bw/day. Commercial squalene at dose of $90 \mathrm{mg} / \mathrm{kg}$ bw/day was less effective in rising HDL cholesterol level than USF $200 \mathrm{mg} / \mathrm{kg}$ bw/day (equivalent to squalene $64.60 \mathrm{mg} / \mathrm{kg}$ bw/day). This finding proved that multi components of bioactive compounds in USF improved blood lipid profile synergistically.

\section{Conclusions}

USF from PFAD that was obtained by saponification contained vitamin E 1.96\% (19.6 mg/g), phytosterols $0.55 \%$ (5.5 mg/g), and squalene $32 \%$ (320 mg/g). Multi component of bioactive compounds in USF synergistically improved blood lipid profile in hipercholesterolaemia condition. USF had a role to decrease blood serum total cholesterol, LDL cholesterol, and triglyceride levels, and concomitantly increased blood serum HDL cholesterol level. Increasing doses of USF resulted in better blood lipid profile improvement. USF was more effective in improving blood lipid profile than commercial squalene supplement.

\section{Acknowledgement}

We are very grateful to Directorate General of Higher Education, Ministry of Education and Culture, Republic of Indonesia for funding this research through MP3EI grant with contract No. 249/SP2H/PL/DIT.LITABMAS/VII/2013, July 15, 2013.

\section{Conflict of Interest}

The authors have no competing interest.

\section{References}

[1] Gapoor, A., Hassan, W.H.W., and M. Sulong. "Phytochemical for nutraceutical from the by product of palm oil refining”. Palm Oil Development 36. 13-19, 2002.

[2] Chu, B.S., Quek, S.Y., and Baharin, B.S. "Optimisation of enzymatic hydrolysis for concentration of vitamin $\mathrm{E}$ in palm fatty acid distillate”. Journal of Food Chemistry 8. 295-302. 2003.

[3] Rakmi, A.R. and Herawan, T. "Properties of biosurfactant enzymatically prepared from fructose and palm fatty acid". Journal of Oil Palm Research 12 (1). 117-122. 2000.

[4] Cheah, K.Y., Toh T.S., and Koh, P.M. "Palm fatty acid distillate biodiesel: next generation palm biodiesel”. Inform. AOCS. 2010.

[5] Nang, H.L.L., Wafti, N.S.A., and May, C.Y. "Palm fatty acid distillate”. МРOB No. 471. МРOB Information Series. June 2009.

[6] Estiasih, T., Ahmadi, K., Widyaningsih, T.D. and Maligan. J.M. 2012. Multi components of bioactive compounds for food supplement and fortificant as an effort to increase economical value of by-product of palm oil refinery. Year 1 MP3EI Report. Research Centre, Brawijaya University, Malang.

[7] Liu, D., Shi, J., Posada, L.R., Kakuda, Y., and Xue, S.J. "Separating tocotrienol from palm oil by molecular ditillation". Food Reviews International. 24. 376-391. 2008.

[8] Posada, L.R., Shi, J., Kakuda, Y., and Xue, S.J. "Extraction of tocotrienols from palm fatty acid distillates using molecular distillation". Journal of Separation and Purification Technology 57. 220-229. 2007.

[9] Khatoon, S., Rajan, R.G.R., and Krishna, A.G.G. "Physicochemical characteristics and composition of Indian soybean oil deodorizer distillate and the recovery of phytosterols". J. Am. Oil Chem. Soc. 87 (3). 321-326. 2010.

[10] Ng, M.H., Chao, Y.M., Ma, A.H., Choah, C.H., and Hashim, M.A.” Separation vitamin E (tocopherol, tocotrienol, and tocomonoenal) in palm oil”. Lipids 39. 1031-1035. 2004.

[11] Puah, C.W., May, C.Y., Ahngan, M., and Hock, C.C. "Degumming and bleaching: Effect on selected constituents of palm oil”. Journal of Oil Palm Research 16. 57-63. 2004.

[12] Lewis, J. Process for the production of tocotrienols. US Patent 6,838,104. 2001.

[13] Taşan, M., Bilgin, B., Geçgel, Ü., and A.Ş. Demirci. "Phytosterols as functional food ingredients". Journal of Tekirdag Agricultural Faculty 3 (2). 153-159. 2006.

[14] Awad A.B. and Fink, C.S. "Phytosterol as anticancer dietary component: evidence and mechanism of action”. J. Nutr. 130. 2127-2130. 2000.

[15] Piironen V., Lindsay, D.G., Mieyyinen, T.A., Toivo, J., and Lampi, A.M. "Plant sterol: biosynthesis, biological function and their importance to human nutrition”. J. Sci. Food Agric. 80. 939-966. 2000.

[16] Ostlund, R.E. Jr, McGill, J.B., Zeng, C.M., Covey, D.F., Stearns, J., Stenson, W.F., and Spilburg, C.A. “Gastraointestinal absorption and plasma kinetics of soy delta (5)-phytosterols and phytostanols in humans”. Am. J. Physiol. Endocrinol. Metab. 282E911-E916. 2002.

[17] Bonsdorff-Nikander, A.V. Studies on a cholesterol-lowering micro crystalline phytosterol suspension oil. Dissertation. University of Helsinki, Helsinki. 2005.

[18] Loganathan, R., Selvaduray, K.R., Radhakrishnan, A., and Nesaretnam, K. "Palm oil rich in health promoting phytonutrients". Palm Oil Development 50. 16-25. 2009.

[19] Qureshi, A.A., Lehmann, J.W., and Peterson, D.M. “Amaranth and its oil inhibit cholesterol biosynthesis in 6-week-old female chickens”. The Journal of Nutrition 126 (8). 1972-1978. 1996.

[20] Shin, D.H., Heo, H.J., Lee, Y.J., and Kim, H.K. "Amaranth squalene reduces serum and liver lipid levels in rats fed a cholesterol diet”. British Journal of Biomedical Science 61 (1). 11-4. 2004.

[21] de Castro, L.Í., Andrade, Soares, R.A., Manólio, Saldiva, P.H.N., Ferrari, R.A., Miguel, A.M. "Amaranth oil increased fecal excretion of bile acid but had no effect in reducing plasma cholesterol in hamsters”. Lipids. 48 (6). 609-18. 2013.

[22] Zengshe, Z., Yeung, W.K., Huang, Y., and Chen, Z-Y. "Effect of squalene and shark liver oil on serum cholesterol level in hamsters". International Journal of Food Sciences and Nutrition 53 (5). 411-418. 2002.

[23] Coskun, A., Serteser, M., and Unsal, I. "Inhibition of cholesterol biosynthesis in hypercholesterolemia-is it the right choice?" J. Med. Biochem. 32. 16-19. 2013.

[24] Ball, G.F.M. Fat-Soluble Vitamin Assays in Food Analysis (A Comprehensive Review). Elsevier Applied Science. London. 1988. 
[25] Mendez, E., Blanco, M., Laguna, A., Garcia, E. "Isolation and characterization of a mixture of higher primary aliphatic alcohols of high molecular weight from henequen (Agave furcroydes L.) wax”. Revista CENIC Ciencias Químicas 34 (1). 35-38. 2003.

[26] Reeves, P.G. "Components of the AIN-93 diets as improvements in the AIN-76A diet”. J. Nutr. 127. 838S-841S. 1993.

[27] Estiasih, T., Ahmadi, K., Widyaningsih, T.D., Maligan, J.M., Mubarok, A.Z., Zubaidah, E., Mukhlisiyyah, J. and Puspitasari, R. "Bioactive compounds of palm fatty acid distillate (PFAD) from several palm oil refineries”. Advance Journal of Food Science and Technology 5 (9). 1153-1159. 2013.

[28] Sheppard, A.J., Penington, J.A.T., and Weihrauch, J.L. Analysis and Distribution of vitamin E In Vegetable Oils and Foods. In: Vitamin E in Health and Disease. Marcel Dekker. New York. 1993.

[29] Moreau, R.A, Lampi, A.M., and Kevin, B.H. "Fatty acid, phytosterol, and polyaamine conjungate profiles of edible oils extracted from corn germ, corn fiber, and corn kernels”. J. Am. Oil Chem. Soc. 86. 1209-1214. 2009.

[30] Melnikov, S.M., Seijen. T., Hoorn, J.W.M., and Bertrand, B. “Can cholesterol absorption be reduced by phytosterols and phytostanols via a cocrystallization mechanism?” Chem. Phys. Lipids 127. 15-33. 2004.

[31] Eussen, R.B.M.S., de Jong, Rompelberg, C.J.M., Garssen, J., Verschuren, W.N.M., and Klunge, O.H. "Dose-dependent cholesterol-lowering effects of phytosterol/phytostanol-enriched margarine in statin users and statin non-users under free-living conditions”. Public Health Nutrition 14 (10). 1823-1832. 2011.

[32] Brown, A.W., Hang, J., Dussault, P.H., and Carr, T.P. 2010. "Phytosterol ester constituents affect micellar cholesterol solubility in model bile”. Lipids 45. 855-862. 2010.

[33] Amiot, M.J., Knol, D., Cardinault, N., Nowicki, M., Bott, R., Antona, C., Borel, P., Bernard, J-P., Duchateau, G., and Lairon, D. "Comparable reduction in cholesterol absorption after two different ways of phytosterol administration in humans". Eur. J. Nutr. 52. 1215-1222. 2013.
[34] Chen, Q., Gruber, H., Swist, E., Coville, K., Pakenham, C., and Ratnayake, W.M.N. "Dietary phytosterols and phytostanols decrease cholesterol levels but increase blood pressure in WKY inbred rats in the absance of salt-loading”. Nutrition \& Metabolism 7 (11). 1-9. 2010.

[35] Kamal-Eldin, A., and Moazzami, A. "Plant sterols and stanols as cholesterol-lowering ingredients in functional foods". Recent Patents on Food, Nutrition \& Agriculture 1. 1-14. 2009.

[36] John, S., Sorokin, A.V., and Thompson, P.D. "Phytosterols and vascular disease”. Curr. Opin. Lipidol. 18. 35-40. 2007.

[37] Bartnikowska, E. "Biological activities of phytosterols with particular attention to their effects on lipid metabolism". Pol. J. Food Nutr. Sci. 59 (2). 105-112. 2009.

[38] Miettinen, T.A. and Vanhanen, H. "Serum concentration and metabolism of cholesterol during rapeseed oil and squalene administration”. Am. J. Clin. Nutr. 59. 356-363. 1994.

[39] Kidd, P.M. "The tocotrienols going (way) beyond vitamin E: building health by building cell membranes: An interview with Barrie Tan, PhD”. Total Health 30 (5). 18-19. 2009.

[40] Hernandez-Mijares, A., Bañuls, C., Rocha1, M., Morillas, C., Martı'nez-Triguero, M.L., V1'ctor, V.M., Lacomba, R., Alegri'a, A., Barbera', R., Farre', R., and Lagarda, M.J. "Effects of phytosterol ester-enriched low-fat milk on serum lipoprotein profile in mildly hypercholesterolaemic patients are not related to dietary cholesterol or saturated fat intake”. British Journal of Nutrition 104. 1018-1025. 2010.

[41] Cohen, D.E. "Balancing cholesterol synthesis and absorption in the gastrointestinal tract”. J. Clin. Lipidol. 2 (2). S1-S3. 2008.

[42] Fairus, S., Nor, R.M., Cheng, H.M., and Sundram, K. "Alphatocotrienol is the most abundant tocotrienol isomer circulated in plasma and lipoproteins after postprandial tocotrienol-rich vitamin E supplementation”. Nutrition Journal 11. 5. 2012

[43] Mahmood, Z.A, Ahmed, S.W., Sualeh, M, and Mahmood, S.B.Z. "Hyperlipidemia development and consequences". Medical Channel, July-September, 2009. 